\title{
Agro-ecological features of the introduction and spread of the highly pathogenic avian influenza (HPAI) $\mathrm{H} 5 \mathrm{~N} 1$ in northern Nigeria
}

\author{
Giuliano Cecchi ${ }^{1}$, Albert Ilemobade ${ }^{1,2}$, Yvon Le Brun ${ }^{1}$, Lenny Hogerwerf ${ }^{1,3}$, Jan \\ Slingenbergh ${ }^{1}$ \\ ${ }^{1}$ Food and Agriculture Organization of the United Nations (FAO), Animal Production and Health \\ Division, Viale delle terme di Caracalla, 00153 Rome, Italy; ${ }^{2}$ Upline Resources Foundation, 54B Oba \\ Adesida Road, P.O. Box 1308, Akure, Ondo State 340001, Nigeria; ${ }^{3}$ Université Libre de Bruxelles, \\ Laboratory of Biological Control and Spatial Ecology, Brussels, Belgium
}

\begin{abstract}
Nigeria was the first African country to report highly pathogenic avian influenza (HPAI) H5N1 virus outbreaks in February 2006 and has since been the most severely hit country in sub-Saharan Africa. A retrospective survey carried out towards the end of 2007, coupled with follow-up spatial analysis, support the notion that the H5N1 virus may have spread from rural areas of northern Nigeria near wetlands frequented by palaearctic migratory birds. Possibly, this could have happened already during November to December 2005, one or two months prior to the first officially reported outbreak in a commercial poultry farm (Kaduna state). It is plausible that backyard poultry played a more important role in the $\mathrm{H} 5 \mathrm{~N} 1$ propagation than thought previously. Farming landscapes with significant numbers of domestic ducks may have helped to bridge the geographical and ecological gap between the waterfowl in the wetlands and the densely populated poultry rich states in north-central Nigeria, where the virus had more sizeable, visible impact.
\end{abstract}

Keywords: influenza A virus, H5N1 subtype, ducks, poultry, wetlands, Nigeria.

\section{Introduction}

The highly pathogenic avian influenza (HPAI) H5N1 virus that first showed up in 1996 in domestic geese in coastal China was unlike any other HPAI event until then in that this virus evolved a clear affinity for domestic and, later on, also for wild waterfowl (Keawcharoen et al., 2008). Since the 1970s there has been a gradual increase in HPAI emergence in poultry industries across the globe with chicken, turkey and also ostrich among the species in which avian influenza $\mathrm{H} 5$ and $\mathrm{H} 7$ viruses were

Corresponding author:

Giuliano Cecchi

FAO Rome, Building C - Room C 512

Viale delle Terme di Caracalla, 00153 Rome, Italy

Tel. +39 06570 53526; Fax +3906570 55749

E-mail: giuliano.cecchi@fao.org; giulianocecchi@libero.it found to switch to a higher pathogenicity level (Alexander, 2007). The presence of terrestrial poultry in areas frequented by avian influenza virus-carrying wild waterbirds may provide for the right setting for a lowly pathogenic avian influenza (LPAI) virus to mutate into a highly pathogenic one. Presumably, the wider the circulation of LPAI in poultry, the higher the chance that mutation to HPAI will occur (Alexander, 2007). Whilst the H5N1 initially turned out to be primarily a domestic goose virus, domestic ducks progressively gained in importance as preferred hosts (Chen et al., 2004). A total of 21 different H5N1 genotypes were found circulating in healthy domestic ducks routinely sampled in live bird markets in coastal and southern China during 1999 to 2002 (Chen et al., 2004). The prevalence of $\mathrm{H} 5 \mathrm{~N} 1$ viruses in ducks increased with the emergence of genotype $\mathrm{Z}$ in 2001-2002, in southern 
China (Hulse-Post et al., 2005). This virus is believed to have paved the way for the first, sub-continentalscale H5N1 epizootic wave, which took place from late 2003 to early 2004. This trans-frontier virus propagation is believed to have been mediated, at least initially, mainly by chicken-related transportation (Sims, 2007; Wang et al., 2008). Chickens are by far the most abundant poultry species in Asia and also worldwide. Chickens are highly susceptible to H5N1 viruses and a near $100 \%$ mortality in the affected flocks was the rule during the first epizootic wave (Sims, 2007). In chickens, virus excretion apparently was sufficient to rapidly spread H5N1 infections across the Mekong countries, with dayold-chicken (DOC) transport, by people travelling with live birds, and vendors supplying live bird markets (LBM). Particularly LBM, which are mainly selling broilers, form a renowned source of HPAI H5N1 persistence and amplification.

Still, the pathways by which the virus spreads probably change with the evolution of the virus (Kilpatrick et al., 2006). As the first epizootic waves of 2004-2005 in Southeast Asia started to settle down, virus persistence was mainly confined to areas with a high number of free ranging ducks, associated with irrigated rice cropping in river deltas, plains and other wetland areas (Gilbert at al., 2007). Whilst HPAI H5N1 viruses readily infect both aquatic and terrestrial poultry, the virus causes a relatively mild infection in ducks and geese. Hence, genetic adaptation is arguably more feasible in aquatic then in terrestrial poultry. The abundant domestic duck congregations in wetland patches would provide the right setting for the virus to evolve into a better domestic waterfowl specialist. The spillback of $\mathrm{H} 5 \mathrm{~N} 1$ viruses from domestic to wild waterfowl became apparent in spring 2005 when thousands of bar-headed geese (Anser indicus) died in April-May 2005 in the Qinghai Lake area in central China (Liu et al., 2005). Since then, evidence has been mounting that migratory waterbirds may become a vector for the H5N1 virus and spread it across the Palaearctic. Available epidemiological and phylogenetic data support the notion that migratory waterbirds facili- tated the spread of a Qinghai virus lineage from the eastern to the western Palaearctic, prompting the emergence of a new virus clade spreading across Europe, the Middle East and also Africa (Salzberg et al., 2007). This east-to-west virus transportation followed the pattern long established for LPAI viruses circulating in migratory waterfowl, with viruses that may travel in only six months from China to Europe or vice versa (Duan et al., 2007).

Re-distribution of viruses among birds using different flyways occurs just after the boreal summer breeding season. For example, Lake Chany, situated in south-western Siberia in between Omsk and Novosibirsk, is one of the locations where birds congregate around July for moulting, before returning towards the wintering areas mainly southwest- and westwards. Presumably, avian influenza viruses become routinely exchanged between birds from eastern and western Palaearctic flyways (Gilbert et al., 2006b). In the area between Omsk and Novosibirsk H5N1 viruses were found circulating in wild and domestic birds during mid-2005 and again mid-2006. In October 2005, the H5N1 virus was first seen in poultry in the Black Sea basin, marking the start of a progressive spread of QinghaiNovosibirsk lineages across Europe, the Middle East and Africa, to become later known as the EMA virus subclade (Salzberg et al., 2007). Turkey was among the countries severely affected during January 2006. A spell of cold weather probably forced H5N1infected mute swans (Cignus olor), wintering in the Caspian Sea basin, westwards into Europe, causing a scatter of $\mathrm{H} 5 \mathrm{~N} 1$ outbreaks here. Soon thereafter, Egypt and Nigeria reported virus incursions. Whilst it is recognized that Egypt and Nigeria are vulnerable to $\mathrm{H} 5 \mathrm{~N} 1$ incursions through poultry trade and traffic, in particular DOC shipments (Birdlife International, 2006), it is also conceivable that $\mathrm{H} 5 \mathrm{~N} 1$ has moved into these countries by the help of wild birds arriving from Siberia and/or staging in the eastern Mediterranean basin. In Asia, the events of HPAI due to H5N1 during 2006-2007 showed ever more evidence for a progressive retraction of virus in areas with major domestic duck congregations 
(Chen et al., 2004). This persistence of H5N1 is typically associated with irrigated rice areas, comprising up to tens of millions of free ranging ducks (Gilbert et al., 2007). The persistence of H5N1 is apparently also enhanced in Egypt by some 45 million ducks which are kept mixed with chicken in backyards and pertaining to single households, mostly women, looking after small or medium-size commercial holdings (Hogerwerf and Siddig, 2007). Also, the Black Sea basin, where H5N1 is frequently encountered in poultry and wild waterbirds, forms a possible concentration area with tens of millions of domestic ducks (FAO, 2008b).

Against this background, the question poses itself if perhaps also Nigeria avails of an interface between wild birds and domestic fowl conducive to H5N1 introduction, from where the virus may have started to spread nationwide in commercial poultry circuits. Hence, a survey was carried out by FAO between 27 November and 6 December 2007 collating retrospective information in a transect running from the Hadejia-Nguru wetlands and associated farming landscapes to the densely populated, poultry-rich areas of Kano and Kaduna states. The mission team visited the Federal Capital Territory (Abuja), Kaduna state (Zaria), Kano state (Kano, Guzuguzi dam, Danbatta and Karaye wetlands and irrigation schemes, Thomas dam), Jigawa state (Dutse, Auyo, Hadejia), and Yobe state (Nguru). During the survey, veterinary officials, scientists, wildlife and wetlands specialists and villagers were interviewed. Visited institutions included, among others, the Federal Department of Livestock and Pest Control Services, the National Bureau of Statistics, State Veterinary Services of Kano and Jigawa states and the HadejiaNguru Wetlands Conservation Project.

\section{$\mathrm{H} 5 \mathrm{~N} 1$ outbreaks in space and in time}

The official outbreak reports indicate that H5N1 viruses were detected in three Nigerian states during January 2006: Kaduna and Kano in the north, and Ogun in the south-west adjacent to Lagos (FAO, 2008a). Phylogenetic data support evidence of mul- tiple introductions that took place within a short period of time (Ducatez et al., 2006; Fasina et al., 2008). At the time of finalizing this paper in August 2008, the World Organization for Animal Health (OIE) mentions 294 outbreaks in birds for Nigeria in its World Animal Health Information Database (WAHID), while the World Health Organization (WHO) web site reports one human case (WHO, 2008). We also explored the database of the Global Animal Health Information System (EMPRES-i) of the FAO Emergency Prevention System for Transboundary Animal and Plant Pests and Diseases programme (EMPRES), which includes 150 confirmed outbreaks in poultry, in addition to one HPAI case in a wild vulture. In comparison to WAHID, the EMPRES-i database provides more detailed information on reported outbreaks, including geographical coordinates. Most of the records in the EMPRES-i concern commercial poultry farms located in the vicinity of towns, and a restricted number of backyard poultry outbreaks, mainly along the road network connecting major cities. For the period 20062007, the last reported outbreak occurred in the southern part of the country in October 2007. At the time of writing this paper in July 2008, four new outbreaks were recorded in four different states in northern Nigeria. As shown in Figure 1, the 20062007 H5N1 outbreaks (according to the FAO EMPRES-i database; FAO, 2008a) are characterized by a distinct spatial and temporal clustering.

In northern Nigeria, over $90 \%$ of the 2006 and 2007 outbreaks occurred during the dry season, from November to March (Fig. 2). We note here the proximity to the Hadejia-Nguru wetlands, where migratory wild ducks pertaining to the western Siberian-Mediterranean-West Africa flyway (including garganey [Anas querquedula], white-faced whistling duck [Dendrocygna viduata], northern pintail [Anas acuta], etc.) arrive in OctoberNovember. This feeds the speculation that the H5N1 virus may have been introduced by migratory birds. After introduction, the virus appears to have spread into western and south-western direction, probably enhanced by the high mobility of 

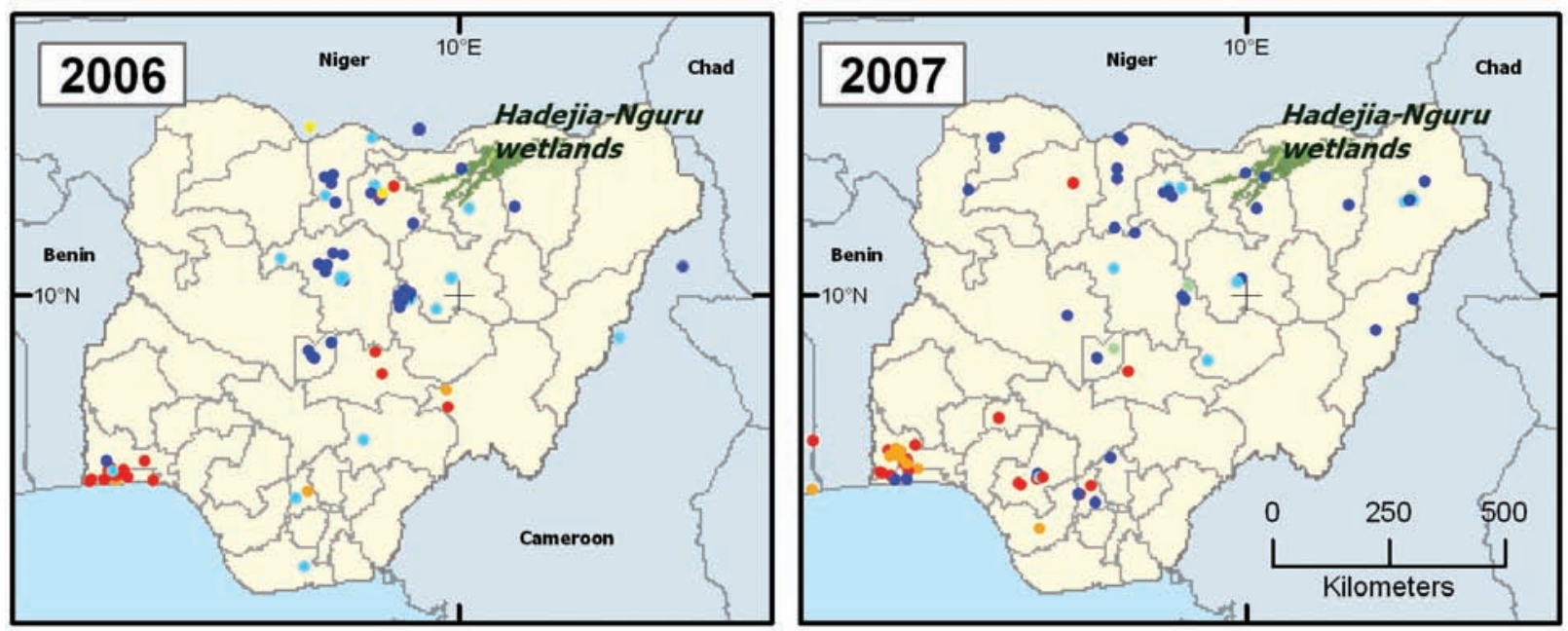

\section{H5N1 outbreaks}

- November

- December

- January

- February

March
- April
May
- June

- July

- August

- September October States

Fig. 1. Approximate locations of reported outbreaks in northern Nigeria, as recorded in the FAO EMPRES-i database.

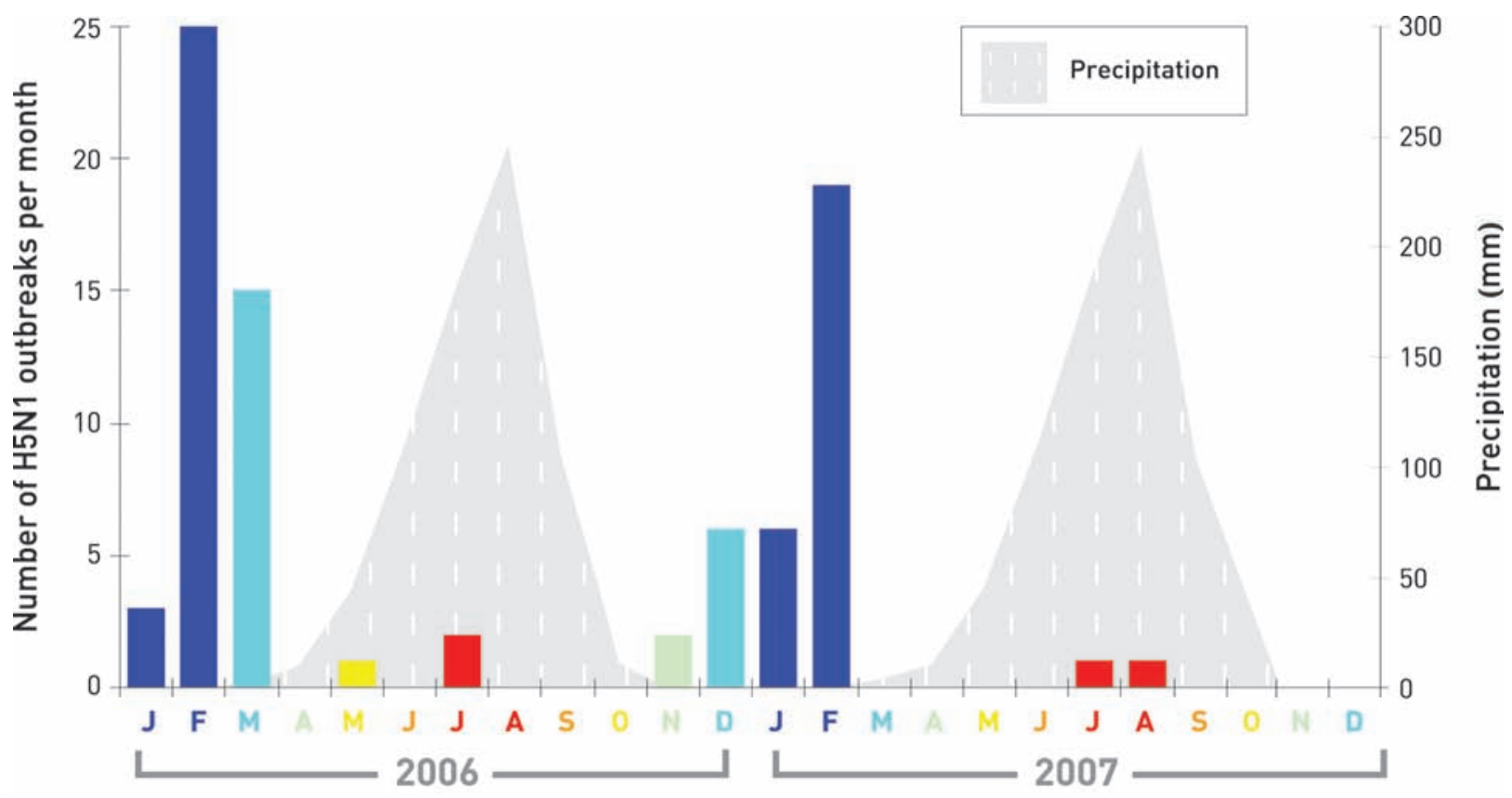

Fig. 2. Monthly reported outbreaks of H5N1 in northern Nigeria (source: FAO EMPRES-i database) and monthly precipitation (Kano, 1960-1990). [Northern Nigeria is here defined as the part of the country lying north of $9^{\circ} \mathrm{N}$ latitude]. 
people and poultry, particularly during the end-ofthe-year holidays and festivities. Also the relatively cooler weather (Harmattan season) may have assisted virus circulation at the onset of the epizootic.

Both the presence of several outbreaks recorded in northern Nigeria during the wet season and the early onset and broad scatter of outbreaks at the start of the second epizootic wave (winter 2006-2007) suggest that the virus had continued to circulate in domestic poultry between the two annual peaks.

Figure 3 suggests clustering of virus persistence in north-central Nigeria, mainly comprising the Kaduna, Plateau, Kano and Bauchi states. Virus persistence in Nigeria during the 2006 wet seasons is also implied by the genetic characterization of circulating H5N1 viruses (Monne et al., 2008).

\section{Migratory birds, wetlands and virus introduction}

As for many other countries, the initial role played by migratory waterbirds remains a much debated subject (Wetlands International, 2006; Kilpatrick et al., 2006; Gauthier-Clerc et al., 2007; Fasina et al., 2008). The official index case dating back to 16 January 2006, and reported to OIE in February 2006, highlights Kaduna state, at approximately
$300 \mathrm{~km}$ distance from the main wetlands (FAO, 2008a). The Ministry of Agriculture considered that commercial trade had brought the virus into Nigeria (Birdlife International, 2006). Later phylogenetic studies pointed to multiple introductions, with viruses matching those detected earlier in western Siberia and the Mediterranean basin (Ducatez et al., 2006).

Information obtained during the current survey, from veterinary field workers and on the basis of reports by village communities, showed widespread mortality of local chickens by an acute poultry disease starting from the rural Jigawa state end 2005 and continuing through early 2006. Jigawa and the neighbouring Yobe state are home to the HadejiaNguru wetlands (Fig. 1), which form the middle section of the Komadugu-Yobe drainage system, in turn part of the Lake Chad basin; most of these wetlands are liable to flooding starting at the end of the rainy season. Rainfall occurs between May and October with the peak in August; inundation lags approximately one month (Thompson and Polet, 2000). During the dry season the flood decreases gradually until April (see Fig. 4). The area is characterized by permanent and seasonal lakes, with a complex pattern of floodplains, mudflats and

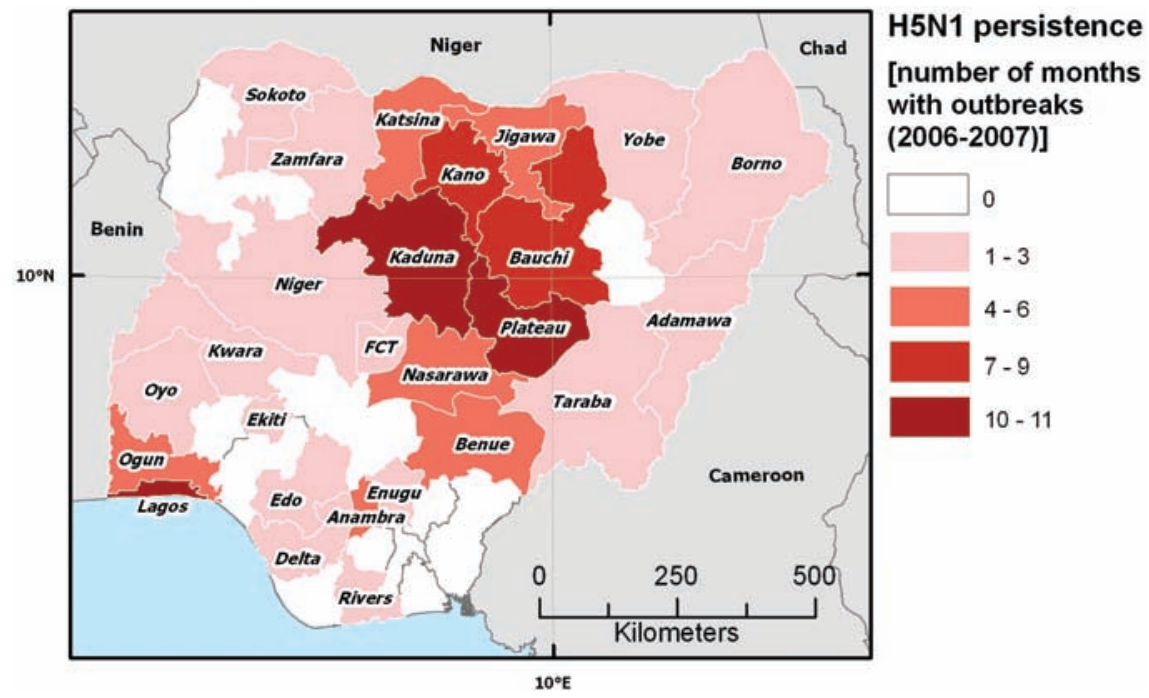

Fig. 3. H5N1 persistence as measured by the cumulative number of months with reported outbreaks (2006-2007) in northern Nigeria (source: OIE WAHID web site). 


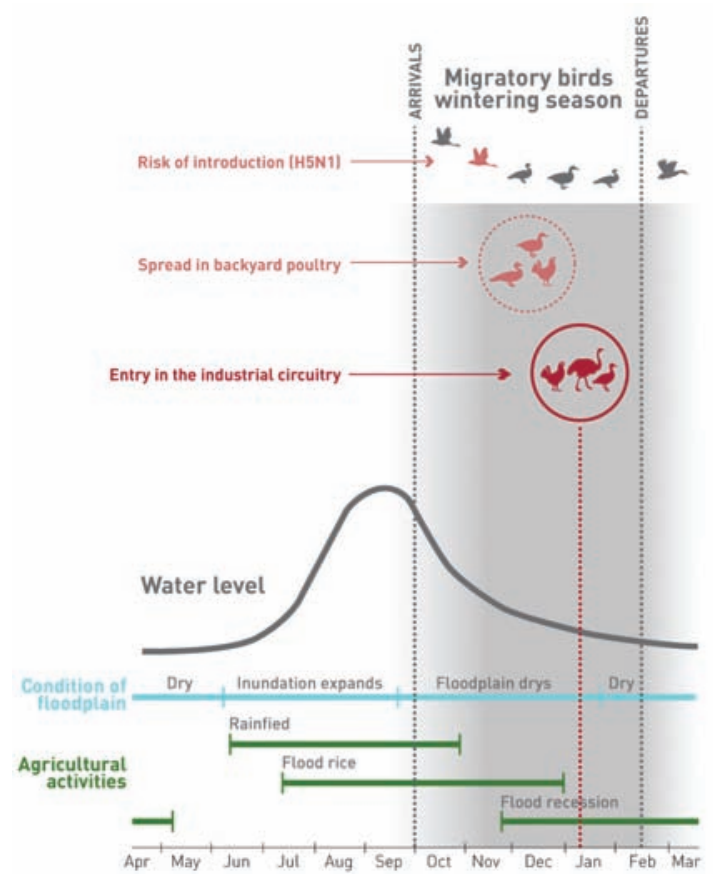

Fig. 4. The seasonality of the annual flood cycle, associated agricultural activities and arrivals of migratory birds in the Hadejia-Nguru wetlands (based on Thompson and Polet, 2000).

marshes (Polet and Becker, 1997), which serve as important habitat for both migratory and resident waterbirds. Wild waterbird counts in the wetlands during the last 10 years estimated the Garganey duck population at 70,000 to 150,000 birds (Polet, 2000; Dutse and Boyi, 2001; Nigerian Conservation Foundation, 2004; Wetlands International, 2007). Ruff (Philomachus pugnax), a medium-sized wader, with a population of approximately 90,000 birds, was the most numerous in the latest survey carried out in 2007 (Wetlands International, 2007). The migration paths ending in the Hadejia-Nguru wetlands intersect with areas in Eastern Europe where $\mathrm{H} 5 \mathrm{~N} 1$ was circulating in the autumn of 2005.

The Hadejia-Nguru wetlands sustain a dense human population and are characterized by intense and complex land-use patterns with extensive wetseason rice farming, flood-recession agriculture, dry-season irrigation, fishing and cattle grazing
(Thompson and Polet, 2000). Poultry rearing is widespread, especially under free-range conditions, and the proximity to water bodies favours significant concentrations of domestic ducks. Hence, the agro-ecological setting and the patterns of land-use in the wetlands are such that the contact between waterbirds and poultry forms a common event. This would support the migratory bird $\mathrm{H} 5 \mathrm{~N} 1$ vector hypothesis, even when concrete evidence is lacking (Gaidet at al., 2007; Wetlands International, 2007). Backyard poultry may readily enter into contact with a diversity of wild birds foraging in cultivated fields, e.g. in rice fields (Tréca, 1992). As reported by local residents and also observed by the survey team, drakes of Muscovy ducks, the most common domestic duck breed in Nigeria, may occasionally join flocks of wild waterfowl, e.g. spur-winged geese (Plectropterus gambensis). Also poaching of wild birds is allegedly a relatively common activity. Hunted wild birds are consumed in loco or transported elsewhere as live birds, reportedly as far as in Lagos state. Captive wild birds are normally kept in village environment before being sold in live-bird markets and they may thus readily enter into contact with poultry.

\section{Domestic ducks, backyard poultry and virus spread and persistence}

Whereas the Hadejia-Nguru wetlands would offer a favourable environment for the introduction of the $\mathrm{H} 5 \mathrm{~N} 1$ virus, the adjacent farming areas that connect to the densely populated states of northcentral Nigeria would provide the right conditions for the onward spread of the virus. The local farming landscape counts significant numbers of domestic ducks. Among the diverse poultry species reared in Nigeria (chicken, guinea-fowls, ducks, pigeons, etc.), domestic ducks may play a role in the persistence of H5N1, as in South-East Asia (Pfeiffer, 2005; Gilbert at al., 2006a) and also in Egypt (Hogerwerf and Siddig, 2007). Whilst there are no recent poultry census data, sample-based estimates compiled by the Nigerian National Bureau of Statistics for 2005 

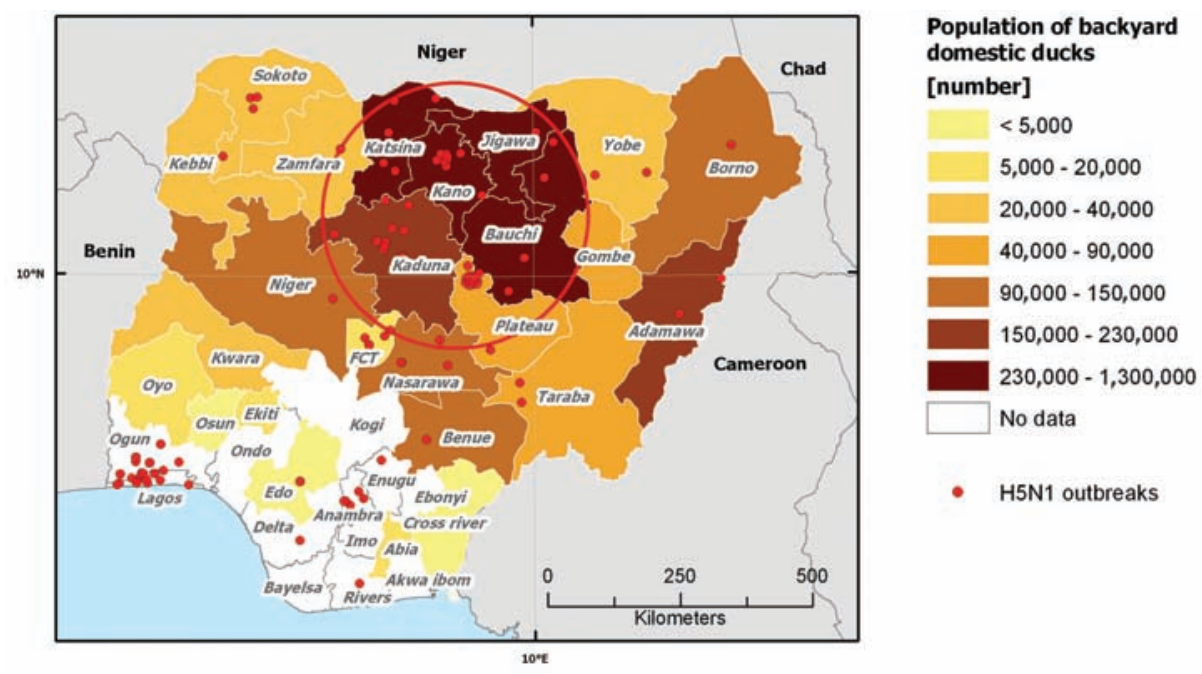

Fig. 5. State-level estimates of backyard domestic ducks populations in Nigeria (source: Nigerian National Bureau of Statistics, cited in Adene and Oguntade, 2006).

(cited in Adene and Oguntade, 2006) provide a broad indication of the local duck abundance. The distribution of subsistence level or backyard ducks (state being the first sub-national administrative unit in Nigeria) is shown in Figure 5. Katsina, Kano, Bauchi and Jigawa states count the highest numbers of domestic ducks. The total population of poultry in Nigeria is estimated at 140 million birds, with the proportion of free-range backyard poultry estimated at between 65 and $80 \%$, increasing northwards (Adene and Oguntade, 2006). Backyard poultry, mainly live chickens and guinea-fowls, are traded from the north in a southwards direction, especially to Lagos. On the basis of the interviews with village communities and collation of non-official local reports, it appears that backyard poultry may have been affected by the disease more severely than official reports indicate, possibly also during the 6-8 weeks preceding the first officially confirmed outbreaks in commercial poultry farms in January 2006.

Statistical analysis confirms that H5N1 persistence (Fig. 3) correlates with both backyard poultry $(\mathrm{P}<0.05)$ and domestic ducks numbers (Fig. 5) $(\mathrm{P}<0.05)$, and not with poultry totals (as derived from FAO, 2007).
Nomadic pastoralists (Fulanis) are users of the Hadejia-Nguru wetlands and may carry domestic ducks along with them during seasonal movements. Hence, also pastoralism, in addition to the floodplain farming landscape with its abundance of domestic ducks, may have facilitated the spread of the $\mathrm{H} 5 \mathrm{~N} 1$ virus towards the urbanized environments in and around Kano state. The proximity of outbreaks to major roads (not shown) is, besides a disease recording bias, indicative of the prominent role played by poultry trade and marketing (Fasina et al., 2008), a common feature throughout Nigeria. It is however likely that surveillance is skewed by the higher visibility of disease in places where poultry and people are more abundant.

\section{Conclusions}

There are multiple pointers suggesting that migratory waterfowl may have contributed to introductions of $\mathrm{H} 5 \mathrm{~N} 1$ viruses that Nigeria experienced towards the end of 2005 and possibly again in late 2006. Information obtained from the HadejiaNguru wetlands and associated farming areas show that both the timing of $\mathrm{H} 5 \mathrm{~N} 1$ introduction and the subsequent pattern of spread fit the notion that wild 
birds, floodplain agriculture and domestic duck husbandry all contributed to H5N1 virus introduction and diffusion. The Hadejia-Nguru wetlands area provides for an ideal meeting place for wild and domestic waterfowl during the months following the retreat of waters in the floodplains. Also, bidirectional traffic of $\mathrm{H} 5 \mathrm{~N} 1$ viruses is, or at least was, possible (Niman at al., 2008). The distinct seasonality of $\mathrm{H} 5 \mathrm{~N} 1$ in poultry in northern Nigeria, with a peak during February 2006, and again in February 2007, is compatible with the hypothesis of $\mathrm{H} 5 \mathrm{~N} 1$ introduction by Palaearctic migratory birds. On the other hand, seasonality is also likely to become enhanced by the end-of-theyear increase in poultry movement associated with religious festivities. Currently available data are not sufficient to fully verify this claim. The broader scatter of outbreaks during the second epidemic wave, its earlier onset, and the fact that outbreaks in several other West African countries were caused by the same virus that was first encountered in northern Nigeria, support the notion that virus persisted throughout 2006. The fact that the viruses circulating in 2007 in Nigeria were in large part reassortant ones based on the 2006 sublineages (Monne at al., 2008) also corroborates this. The differentiation between repeated introduction or persistence, or a combination of both, is relevant for local virus evolution and virus elimination prospects for West Africa as a whole. If H5N1 is indeed capable of persisting on a year-round basis, it is important to further disentangle $\mathrm{H} 5 \mathrm{~N} 1$ virus seasonality and procure more adequate baseline data.

It is possible that $\mathrm{H} 5 \mathrm{~N} 1$ has been overlooked in the backyard sector. Apart from the lesser visibility of $\mathrm{H} 5 \mathrm{~N} 1$ virus circulating in scattered, small-sized flocks, the significance of H5N1 in backyard poultry may have been underestimated because of:

(i) the limited knowledge of the disease among rural poultry keepers and veterinary staff, at least during the early stage of the epizootic;

(ii) Newcastle disease confounding HPAI diagnosis (Newcastle disease is much better known to farmers in northern Nigeria; Nwanta et al., 2006); and

(iii) the remoteness of the rural farmers, out of reach of veterinary services.

Hence, enhanced surveillance in the remote rural environments would help to clarify the role of the backyard sector, provided domestic ducks are given priority consideration.

\section{Acknowledgments}

We thank Dr. Junaidu Maina, Director of the Federal Department of Livestock and Pest Control Services (Nigeria), and his staff for the assistance and logistic support provided during the mission to Nigeria. This research has been supported by the Food and Agriculture Organization of the United Nations (FAO). Comments by Drs Scott Newman and Taej Mundkur are gratefully acknowledged.

\section{References}

Adene DF, Oguntade AE, 2006. The structure and importance of the commercial and village based poultry industry in Nigeria. FAO, Rome, Italy.

Alexander DJ, 2007. An overview of the epidemiology of avian influenza. Vaccine 25, 5637-5644.

Birdlife International, 2006. Illegal imports probable cause of Nigeria flu. Available at: http://www.birdlife.org/news/ news/2006/02/avian_flu_nigeria.html (Accessed: 12 August 2008).

Chen H, Deng G, Li Z, Tian G, Li Y, Jiao P, Zhang L, Liu Z, Webster RG, Yu K, 2004. The evolution of H5N1 influenza viruses in ducks in southern China. Proc Natl Acad Sci USA 101, 10452-10457.

Duan L, Campitelli L, Fan XH, Leung YH, Vijaykrishna D, Zhang JX, Donatelli I, Delogu M, Li KS, Foni E, Chiapponi C, Wu WL, Kai H, Webster RG, Shortridge KF, Peiris JSM, Smith Gavin JD, Chen H, Guan Y, 2007.Characterization of low-pathogenic H5 subtype influenza viruses from Eurasia: implications for the origin of highly pathogenic H5N1 viruses. J Virol 81, 7529-7539.

Ducatez MF, Olinger CM, Owoade AA, De Landtsheer S, Ammerlaan W, Niesters HG, Osterhaus AD, Fouchier RA, Muller CP, 2006. Avian flu: multiple introductions of 
H5N1 in Nigeria. Nature 442, 37.

Dutse IS, Boyi MG, 2001. The 2001, dry season survey of waterfowl in the Hadejia-Nguru wetlands, Nigeria.

FAO, 2007. Gridded livestock of the world 2007. FAO, Rome, Italy.

FAO, 2008a. Global animal disease information system (EMPRES-i). FAO, Rome, Italy.

FAO, 2008b. FAOSTAT. Available at: http://faostat.fao.org/ (Accessed: 12 August 2008).

Fasina FO, Bisschop SP, Joannis TM, Lombin LH, Abolnik C, 2008. Molecular characterization and epidemiology of the highly pathogenic avian influenza $\mathrm{H} 5 \mathrm{~N} 1$ in Nigeria. Epidemiol Infect 17, 1-8.

Gaidet N, Dodman T, Caron A, Balança G, Desvaux S, Goutard F, Cattoli G, Lamarque F, Hagemeijer W, Monicat F, 2007. Avian influenza viruses in water birds, Africa. Emerg Infect Dis 13, 626-629.

Gauthier-Clerc M, Lebarbenchon C, Thomas F, 2007. Recent expansion of highly pathogenic avian influenza H5N1: a critical review. Ibis 149, 202-214.

Gilbert M, Chaitaweesub P, Parakamawongsa T, Premashthira S, Tiensin T, Kalpravidh W, Wagner H, Slingenbergh J, 2006a. Free-grazing ducks and highly pathogenic avian influenza, Thailand. Emerg Infect Dis 12, 227-234.

Gilbert M, Xiao X, Chaitaweesub P, Kalpravidh W, Premashthira S, Boles S, Slingenbergh J, 2007. Avian influenza, domestic ducks and rice agriculture in Thailand. Agric Ecosyst Environ 119, 409-415.

Gilbert M, Xiao X, Domenech J, Lubroth J, Martin V, Slingenbergh J, 2006b. Anatidae migration in the western Palearctic and spread of highly pathogenic avian influenza H5N1 virus. Emerg Infect Dis 12, 1650-1656.

Hogerwerf L, Siddig A, 2007. Ducks and HPAI H5N1 in the Nile delta, Egypt. Consultancy report to FAO. FAO, Rome, Italy.

Hulse-Post DJ, Sturm-Ramirez KM, Humberd J, Seiler P, Govorkova EA, Krauss S Scholtissek C, Puthavathana P, Buranathai C, Nguyen TD, Long HT, Naipospos TS, Chen H, Ellis TM, Guan Y, Peiris JS, Webster RG, 2005. Role of domestic ducks in the propagation and biological evolution of highly pathogenic H5N1 influenza viruses in Asia. Proc Natl Acad Sci USA 102, 10682-10687.

Keawcharoen J, van Riel D, van Amerongen G, Bestebroer T, Beyer WE, van Lavieren R, Osterhaus AD, Fouchier RA,
Kuiken T, 2008. Wild ducks as long-distance vectors of highly pathogenic avian influenza virus (H5N1). Emerg Infect Dis 14, 600-607.

Kilpatrick AM, Chmura AA, Gibbons DW, Fleischer RC, Marra PP, Daszak P, 2006. Predicting the global spread of H5N1 avian influenza. Proc Natl Acad Sci USA 103, 19368-19373.

Liu J, Xiao JH, Lei F, Zhu Q, Qin K, Zhang XW, Zhang XL, Zhao D, Wang G, Feng Y, Ma J, Liu W, Wang J, Gao GF, 2005. Highly pathogenic H5N1 influenza virus infection in migratory birds. Science 309, 1206.

Monne I, Joannis TM, Fusaro A, de Benedictis P, Lombin LH, Ularamu H, Egbuji A, Solomon P, Obi TU, Cattoli G, Capua I, 2008. Reassortant avian influenza virus (H5N1) in poultry, Nigeria, 2007. Emerg Infect Dis 14, 637-640.

Nigerian Conservation Foundation, 2004. Annual water birds census. Nigerian Conservation Foundation.

Niman HL, Aly MM, Arafa AS, El-Sayed N, Nayel AE, Abdelghani AS, Esmat HM, Raczniak GA, Agyen-Frempong M, Ampofo WK, Boynton BR, 2008. Concurrent acquisition of a single nucleotide polymorphism in diverse influenza H5N1 clade 2.2 sub-clades. Nature Precedings, available at: http://precedings.nature.com/documents/459/version/4 (Accessed: 12 August 2008).

Nwanta JA, Umoh JU, Abdu PA, Ajogi I, Ali-Balogun JK, 2006. Management of losses and Newcastle disease in rural poultry in Kaduna State, Nigeria. Niger J Anim Prod 33, 274-285.

Pfeiffer DU, 2005. Assistance in the geospatial analysis of HPAI outbreaks in Vietnam. Report based on Consultancy Mission OSRO/RAS/401/JPN. FAO, Rome, Italy.

Polet G, 2000. Waterfowl and flood extent in the HadejiaNguru wetlands of north-east Nigeria. Bird Conserv Int 10, 203-209.

Polet G, Becker I, 1997. The Hadejia-Nguru Wetlands. Nigerian Field 62, 13-23.

Salzberg SL, Kingsford C, Cattoli G, Spiro DJ, Janies DA, Aly MM, Brown IH, Couacy-Hymann E, De Mia GM, Dung do H, Guercio A, Joannis T, Maken Ali AS, Osmani A, Padalino I, Saad MD, Savic V, Sengamalay NA, Yingst S, Zaborsky J, Zorman-Rojs O, Ghedin E, Capua I, 2007. Genome analysis linking recent European and African influenza (H5N1) viruses. Emerg Infect Dis 12, 713-718. 
Sims LD, 2007. Lessons learned from Asian H5N1 outbreak control. Avian Dis 51, 174-181.

Thompson JR, Polet G, 2000. Hydrology and land use in a Sahelian floodplain wetland. Wetlands 20, 639-659.

Tréca B, 1992. Water birds and rice cultivation in west Africa. Proceedings VII Pan-African Ornithological Congress, 297-301.

Wang J, Vijaykrishna D, Duan L, Bahl J, Zhang JX, Webster RG, Peiris JS, Chen H, Smith GJ, Guan Y, 2008. Identification of the progenitors of Indonesian and Vietnamese avian influenza A (H5N1) viruses from southern China. J Virol 82, 3405-3414.
Wetlands International, 2006. Response on the outbreak of HPAI H5N1 in poultry in northern Nigeria. Facts about the outbreak and the risks. Wetlands International, Wageningen, The Netherlands.

Wetlands International, 2007. Data on waterbirds for avian influenza and surveillance in the African-Eurasian flyway, 2007. Final technical report. Unpublished report to WCS/USAID. Wetlands International, Wageningen, The Netherlands.

WHO, 2008. Cumulative number of confirmed human Cases of avian influenza $\mathrm{A} /(\mathrm{H} 5 \mathrm{~N} 1)$ reported to WHO. WHO, Geneva, Switzerland. 